Jurnal Konstruksi Hukum | ISSN: 2746-5055

Vol. 2, No. 2, Mei 2021, Hal. 350-355| Tersedia online di

https://www.ejournal.warmadewa.ac.id/index.php/jukonhum

DOI: https://doi.org/10.22225/jkh.2.2.3254.350-355

\title{
IMPLEMENTASI PEMASANGAN REKLAME BERDASARKAN PERATURAN WALIKOTA DENPASAR NOMOR 3 TAHUN 2014 TENTANG PENYELENGGARAAN REKLAME
}

\author{
Ida Bagus Gde Wisnu Wardhana, I Ketut Kasta Arya Wijaya, Luh Putu Suryani \\ Fakultas Hukum, Universitas Warmadewa, Denpasar - Bali, Indonesia \\ idabaguswisnu01@gmail.com, kastaaryawijaya@gmail.com, putusuryani099@gmail.com
}

\begin{abstract}
Abstrak
Penyelenggaraan reklame melalui pemasangannya saat ini tidak mengikuti prosedur sesuai dengan ketentuan hukum yang ada sehingga menimbulkan kesan ketidak teraturan di sepanjang ruas jalan di Kota Denpasar yang dinilai merusak nilai estetika dan kebersihan karena penataannya kurang baik. Pada dasarnya fungsi reklame untuk menyampaikan informasi, namun apabila ketidakaturan dalam pemasangannya maka masyarakat enggan untuk melihat isi dari reklame tersebut, Maka diperlukan aturan hukum terkait permasalahan ini. Metode penelitian ini menggunakan metode penelitian hukum empiris, kemudian pendekatan dilakukan secara sosiologi. Data primer dari penelitian ini yaitu dengan melakukan wawancara ke Kantor Satuan Polisi Pamong Praja Kota Denpasar (Satpol PP). Selain itu penggunaan Peraturan Walikota Denpasar Nomor 3 Tahun 2014 tentang Penyelenggaraan Reklame. hingga buku-buku literatur, jurnal-jurnal terkait juga membantu penelitian ini. Penelitian ini bertujuan untuk mengetahui Tata Cara/Prosedur Dalam Pemasangan Reklame Berdasarkan peraturan Walikota Denpasar Nomor 3 Tahun 2014 dan Penertiban Pemasangan Reklame Berdasarkan Peraturan Walikota Denpasar Nomor 3 Tahun 2014. Hasil penelitian ini menunjukkan bahwa IMB-R dan SIPR hanya dapat diterbitkan sesuai kebutuhan penyelenggara reklame berdasarkan Peraturan Walikota Denpasar Nomor 3 Tahun 2014, dalam melakukan penertiban reklame yang tidak memiliki izin IMB-R dan SIPR berdasarkan Peraturan Walikota Denpasar Nomor 3 Tahun 2014 dilakukan oleh Organisasi Pemerintah Daerah Kota Denpasar berdasarkan keputusan Walikota Denpasar Nomor 188.45/422/HK/2013 tentang pembentukan tim penyelenggaraan reklame Kota Denpasar. Penertiban pemasangan reklame yaitu teguran tertulis kepada penyelenggara reklame dan pembongkaran reklame.
\end{abstract}

Kata Kunci : Implementasi, Peraturan Walikota, Reklame

\begin{abstract}
The implementation of billboards through their installation at this time still does not follow the procedures regulated by the existing legal regulations, resulting in an impression of disorder along roads in Denpasar City which are considered to be damaging to aesthetic and cleanliness values due to poor arrangement. Basically the function of billboards is to convey information, but if there is an irregularity in the installation, the public is reluctant to see the contents of it, so legal rules are needed related to this issue. This method used is empirical research, then the approach is carried out sociologically. Primary data from this research is by conducting interviews with the Denpasar City Civil Service Police Unit (Satpol PP). In addition, the use of Denpasar Mayor Regulation Number 3 of 2014 concerning the Implementation of Advertising. to literature books, related journals also help this research. This research aims to determine the procedures / procedures for the installation of billboards based on the regulation of the Mayor of Denpasar Number 3 of 2014 and the control of the installation of advertisements based on the Regulation of the Mayor of Denpasar Number 3 of 2014. The result of the research indicates that IMB-R and SIPR can only be issued according to the needs of the advertisement organizer based on the Regulation of the Mayor of Denpasar Number 3 of 2014, in controlling billboards that do not have IMB-R and SIPR permits based on the Regulation of the Mayor of Denpasar Number 3 of 2014 carried out by the Organization. The Regional Government of Denpasar City based on the Decree of the Mayor of Denpasar Number 188.45 / 422 / HK / 2013 concerning the formation of a team for organizing the Denpasar City billboard. Controlling the installation of billboards, namely written warnings to advertisement organizers and demolition of billboards.
\end{abstract}

Keywords: Implementation, Mayor Regulation, Billboard 


\section{PENDAHULUAN}

Dalam hal mempromosikan suatu bisnis atau usaha hingga politik sekalipun, peran reklame sangat penting adanya, namun penyelenggaraan reklame khususnya di Kota Denpasar masih banyak terlihat terjadinya ketumpang tindihan saru sama lain, yang mana masih banyak penyimpangan serta pelanggaran terjadi terkait penyelenggaraannya, seperti dalam hal tempat pemasangannya yang kurang parut. Tidak asing kita lihat di sepanjang jalan dihiasi dengan pemandangan reklame dalam bentuk Billboard spanduk hingga LED. Dimana kita lihat pernasangan seperti reklame dalam bentuk kertas atau spanduk yang masih tak teratur dan membuat tiang, tembok dan jalan tapak kotor karena berantakan seakan pemasangannya memang tak pada tempatnya yang seharusnya. Hal inilah yang merusak pemandangan dan estetika di jalan, terkait pula kebersihan dan penataan di jalan. Untuk iru, dampak negatiF dirasakan, mengingat reklame ini merusak keindahan kota, khususnya di sepanjang ruas jalan, sehingga memberi kesan kumuh, dan tak mungkin dapat membahayakan para pengguna jalan (Wirianto, 2010:7).

Karena digunakan sebagai media promosi salah satunya, fungsi reklame semakin disukai masyarakat, mengingat dapat juga sebagai media untuk menyampaikan pesan sosial misalnya, itulah mengapa perannya begitu penting saat ini. Namun hat ini haus berbanding lurus dengan keteraturan dalam pemasangannya, estetika serta keindahan harus tetap diperhatikan, seperti membenruk keserasian antara luas tempat dan kondisinya dengan reklame yang digunakan. Maka diperlukan untuk memperhatikan beberapa ha! tertentu ketika ingin memasangnya (Wirianto, 2010: 19).

Melalui tugas pembantuan yang diatur dalam UU Pemda No.23 tahun 2014, Walikota sebagai salah satu wujud Pemda Kota memiliki wewenang untuk mengurusi serta mengatur urusan pemerintahannya sendiri. Untuk itu, begitu juga dalam hal ini yaitu Penyelenggaraan reklame juga merupakan wewenang Kota Denpasar dalam pengarurannya. Selain terkait perekonomian, pengaturan reklame juga menyangkut beberapa hal seperti konsep tata ruang kota, sehingga menciptakan keteraturan, serta keindahan dalam penyelenggaraannya. Peraturan Walikota Denpasar Tentang Penyelenggaraan reklame Nomor 3 Tahun 2014 memberikan pengaturan juga di dalamnya terkait syarat, prosedur pengajuan izin dalam pemasangan suatu reklame. Namun tak ayal masih banyak terjadi pelanggaran walau peraturan telah banyak tersedia. Disinilah perlu adanya dukungan dari berbagai kalangan seperti instansi terkait hingga masyarakat unruk melakukan penjaminan bahwa rujuan dari adanya Peraturan Walikota Denpasar tersebut dapat tercapai sedemikian rencananya (Sunamo, 2012: 15).

Peraturan dibentuk untuk mencegah terjadinya pelanggaran terkait penyelenggaraan reklame tersebut, sehingga untuk itu penegakan hukumnya juga diharapkan mampu menyaring reklame yang ada, agar semua memenuhi prosedur dan mendapat izin dalam penyelenggaraannya. Dimana suatu reklame dipasang atau didirikan sesuai pada tempatnya itu dinamakan titik reklarne sebagaimana ketenruan Perwali Denpasar tersebut mengaturnya. Maka perlu dilakukan pengawasan serta penindakan jika terdapat pemasangan reklame yang tak sesuai pada tempatnya atau titik reklame tersebut, sehingga menimbulkan dampak negatif terkait kebersihan, keamanan, hingga mengurangi nilai estetika ruas jalan atau keindahan jalan sepanjang kota Denpasar. Pengguna jalan pun aman serta nyaman melihat jalan yang tersusun rapi.

Menurut Sugeng \& Sekarsari (2019) Pada dasarnya mekanisme pemasangan papan reklame telah ada, contohnya papan reklame harus dipasang pada tempat yang tidak mengganggu kepentingan publik. Apabila mekanisme ini tidak dipatuhi maka akan berdampak pada terganggunua keamanan dan kenyamanan publik. Sudah sepatutnya ada kebijakan dari pemerintah dalam pembangunan papan reklame, baliho, spanduk-spanduk iklan, salah satunya dengan menerbitkan peraturan daerah untuk pengaturan dan penataan reklame (Siregar \& Suri, 2018) Maka dari itu pemberian sanksi sangat diperlukan, mengingat selama ini pemberian sanksi kepada pelaku masih tergolong ringan yang dikarenakan pemberian sanksi mayoritas hanya sebatas sanksi administratif yang tidak terlalu memberikan efek jerah pada setiap pelaku yang melanggar hukum. Hal ini dapat ditinjau meningkatnya pelanggaran reklame setiap tahunnya (Boediningsih \& Wijaya, 2015)

Maka berdasarkan uraian diatas, penelitian ini bertujuan untuk mengetahui Tata Cara/Prosedur Dalam Pemasangan Reklame Berdasarkan peraturan Walikota Denpasar Nomor 3 Tahun 2014 dan Penertiban Pemasangan Reklame Berdasarkan Peraturan Walikota Denpasar Nomor 3 Tahun 2014. 


\section{METODE PENELITIAN}

Dalam penyusunan setiap penelitian ini digunakan metode penelitian hukum empiris, yang mana perujukannya berdasarkan pada pendekatan sosiologi hukum. Data primer adalah data yang diperoleh di tempat penelitian yaitu dengan melakukan wawancara ke Kantor Satuan Polisi Pamong Praja Kota Denpasar (Satpol PP). Selain itu penggunaan Peraturan Walikota Denpasar Nomor 3 Tahun 2014 tentang Penyelenggaraan Reklame. hingga buku-buku literatur, jurnal-jurnal terkait juga membantu penelitian ini

\section{HASIL DAN PEMBAHASAN}

\section{Tata Cara/Prosedur Dalam Pemasangan Reklame Berdasarkan Peraturan Walikota Denpasar Nomor 3 Tahun 2014}

Kumpulan dari suatu rancangan untuk dijadikan dasar atau fondasi dalam bertindak serta penerapannya disebut Kebijakan. Peraturan serta hukum tak sama dengan yang namanya strategi. lstilah kebijakan serta strategi biasa kita jumpai dan dibuat oleh kelompok baik swasta atau bukan hingga di kalangan pemerintahan. Suatu prosedur memiliki pengertian sebagai suatu konsep atau rancangan dalam membuat suaru persiapan terkait realisasinya, tata cara hingga kepernimpinan.

Dalam melakukan penyelenggaraan reklame diharuskan dalam hal kepernilikan izin untuk mendirikannya atau disebut IMB-R serta disamping itu diperlukanjuga SIPR atau Surat izin menyelenggarakannya, yang mana badan yang berwenang menerbitkannya adalah Lembaga PTSP yairu Perizinan terpadu satu Pin tu bersama dengan Dinas Penanaman Modal. Ada pun beberapa jenis reklame yang wajib mendapatkan izin tersebut adalah reklame berjenis videotron, LED, megatron hingga billboard papan besar. Izin ini nantinya memiliki fungsi untuk mengarur hingga menertibkan segala kegiatan yang akan dilaksanakan begiru juga dengan pemasangan reklame (Sutedi, 20 10: 193).

Dalam melakukan pemasangan suatu reklame diperlakukan memperhatikan beberapa aspek seperti terkait estetika serta keindahannya, tak boleh melakukan pemasangan secara sembarangan atau asal pasang saja. Prosedur, syarat serta tata cara telah diatur sedemikian rupa dalam aturan hukum pemerintah, sehingga perusahaan iklan yang ingin melakukan pemasangan, sebagaimana Perwali Denpasar No. 3 tahun 2014 rnengarur haruslah disesuaikan dan ditaati. Untuk itu perlunya izin jika ingin melakukan pemasangan setiap reklame yang ingin dipasang, serta ketentuan harus disesuaikan juga seperti ukuran reklame dengan tempat atau titik reklarne yang disediakan rnisalnya. Selain itu pengkajian juga dilakukan Tim Teknis Perizinan ketika pemasangan dilakukan yang mana panggung reklame tak boleh melebihi $24 \mathrm{~m}$ luasnya.

Tim Teknis Perizinan Reklame merupakan tim yang memiliki rugas dalam mengkaji baik secara konstruksi hingga teknis maupun estetika dari reklame yang akan didirikan atau dipasang, dimana ada unsur SKPD Kota Denpasar dalam susunan personalianya yang mernbantu melakukan pengawasan dalam pernasangan reklame serta penempatannya, agar sesuai dengan titiknya dan tetap menjaga nilai keindahan serta keamanan di sepanjang are tersebut. Sedangkan Tim ini nantinya juga bertugas menentukan lokasi di titik mana reklame dapat dipasang atau ditempatkan.

Keindahan dengan memperhatikan estetika dapat terjamin adanya di sepanjang ruas jalan asalkan pemasangan reklame dilaksanakan sesuai pada tempatnya dan dilakukan pengaturan dengan baik serta pengawasan juga pastinya sangat diperlukan. Monitoring berkala untuk mengecek apakah reklame masih layak pasang juga diperhatikan, sehingga menjamin keamanan serta kenyamanan pengguna jalan khususnya di sepanjang ruas jalan di Kota Denpasar. Aspek lainnya yaitu aman bagi lingkungan sekitar reklame termasuk bagi pengguna jalan dan pejalan kaki, artinya reklame tidak ditempatkan pada zona sirkuasi pejalan kaki atau zona lalu lintas (Nurkukuh, 2019).

Dalam hal suatu perusahaan iklan tak memenuhi prosedur pemasangan reklame sebagaimana disyaratkan dan diatur dalam peraturan hukum yang ada maka mereka tak akan mendapatkan lampu hijau terkait penerbitan izin yang diinginkan, dan jika mereka tetap melanggar aturan tersebut dengan melakukan pemasangan secara ilegal maka untuk itu Tim Teknis Perizinan tadi bersama Tim Penertiban Reklame selaku juga penyidik di lingkungan Pemda, berwenang untuk menyidik kegiatan tersebut dan ditindak secara hukum pidana. Selain itu sanksi administrasi juga dikenakan berupa pencabutan izin hingga pencopotan reklame atau penurunan/pembongkaran reklame yang terpasang atas perintah Walikota. Terkait pengajuan izin untuk melakukan pemasangan reklame baru atau melalui pelelangan titik reklarne tidak diizinkan dan tidak diperkenankan bagi perusahaan iklan itu untuk turut serta setidaknya hingga 1 tahun lamanya semenjak pencabutan reklame karena 
pelanggaran itu dilakukan. Berdasarkan uraian yang telah dijelaskan di atas dapat disimpulkan bahwa mengenai prosedur pemasangan reklame di Kota Denpasar, pemasangan reklame harus memperhatikan aspek estetika Kota Denpasar sebagaimana yang tercantum dalam Peraturan Walikota Denpasar Nomor 3 Tahun 2014, penyelenggara reklame harus memenuhi persyaratan administrasi berdasarkan ketentuan yang terdapat pada pasal 16 bab IV Peraturan Walikota Denpasar tentang penyelenggaraan reklame di Kota Denpasar. Apabila ditemukan reklame yang tidak sesuai dengan prosedur dan tidak memiliki izin pemasangan reklame dapat dikenakan sanksi administrasi berupa pencabutan izin pemasangan, pembongkaran dan penurunan terhadap reklame yang telah dipasang serta sanksi administrasi berupa tidak diperkenankan mengajukan izin penyelenggaraan reklame yang baru dalam jangka waktu 1 tahun terhitung sejak tanggal pencabutan.

\section{Penertiban Pemasangan Reklame Berdasarkan Peraturan Walikota Denpasar Nomor 3 Tahun 2014}

Fungsi reklame semakin disukai masyarakat, mengingat dapat juga sebagai media untuk menyampaikan pesan sosial misalnya, itulah mengapa perannya begitu penting saat ini. Namun ha! ini haus berbanding lurus dengan keteraturan dalam pemasangannya, estetika serta keindahan harus tetap diperhatikan, seperti membentuk keserasian antara luas tempat dan kondisinya dengan reklame yang digunakan. Maka diperlukan untuk memperhatikan beberapa hal tertentu ketika ingin memasangnya (Wirianto 2010: 19).

Dalam hukum serta ilmu pemerintahan, wewenang merupakan hal yang sentral dan sangat penting penerapannya. Mengingat pemerintahan baru akan berjalan dengan baik dengan segala fungsinya juga akan berjalan jika wewenang itu ada dan diperoleh. Setiap hal berjalan atas dasar dari wewenang yang diberikan padanya (Nurcholis, 2007:30).

Keadaan ketika kita mampu untuk melaksanakan suatu tindakan hukum yang mana nantinya hal tersebut dapat menimbulkan suatu akibat hukum, serta di dalamnya berkaitan pula dengan timbul lenyapnya suatu akibat hukum tersebut, itu dinamakan kewenangan. Begitu pula hak yang di dalamnya menganut kebebasan dalam berbuat atau tidak berbuat suatu tindakan tertentu atau melakukan peruntukan kepada orang lain untuk berbuat sesuatu, yang mana disisi lain kewajiban memuat suatu yang harus dan atau tak boleh untuk dilakukan atau diperbuat. (Ridwan HR, 2011: 102)

Satuan Kerja Perangkat Daerah atau SKPD Kota Denpasar sebagaimana diatur dalam Perwali Denpasar tentang penyelenggaraan reklame No. 3 Tahun 2014 ini tentunya pada pasal 25 sudah tertera bahwa memang SKPD yang memiliki tugas mengawasi terkait penyelenggaraan reklame di Kota Denpasar, yang merupakan anggota tim penyelenggaraan reklarne. Berdasarkan hasil wawancara pada tanggal I Desember 2020 dengan Bapak Anak Agung Bagus Jimnantara Putra, SH selaku Kepala Seksi Penyelidikan, Penyidikan dan Penindakan Satuan Polisi Pamong Praja Kota Denpasar, Saruan Polisi Pamong Praja Kota Denpasar memiliki tugas pembongkaran terhadap reklame yang melanggar, seperti reklame tanpa izin, reklame yang telah dicabut izinnya dan belum dibongkar oleh penyelenggara reklame, reklame yang telah berakhir masa berlakunya dan tidak diperpanjang izinnya.

Satuan Polisi Pamong Praja Kota Denpasar bertugas membongkar reklame yang tidak sesuai dengan izin yang telah diberikan antara lain meliputi perubahan teks/isi pesan reklame, perubahan ukuran reklame, perubahan bentuk reklame. Perubahan teks/isi pesan reklame yang dimaksud adalah reklame yang awalnya berupa produk makanan kemudian berubah menjadi produk lain seperti reklame rokok. Disebutkan juga oleh Bapak Anak Agung Bagus Jimnantara Putra, SH selaku Kepala Seksi Penyelidikan, Penyidikan dan Penindakan Satuan Polisi Pamong Praja Kota Denpasardalam wawancara tanggal 1 Desember 2020, Badan Pelayanan Perizinan Terpadu Satu Pintu dan Penanaman Modal (BPPTSP dan PM) berwenang dalam persyaratan permohonan izin penyelenggaraan reklame, pengurusan izin reklame yang berstatus perpanjangan ataupun permohonan izin reklame baru, serta pengawasan terhadap materi rekJame yang akan diterbitkan atau diiklankan, dan pengawasan atas Surat lzin Penyelenggaraan Reklame (SIPR) yang telah diterbitkan. Pengawasan surat izin tersebut berupa kesesuaian titik tepat, jenis, ukuran reklame yang dipasang dengan surat izin yang diberikan.

Disebutkan juga Dinas Tata Ruang dan Perumahan berwenang melakukan pengawasan terhadap Izin Mendirikan Bangunan Reklame (JMB-R), terdiri atas: kepemilikan peta lokasi, kepemilikan gambar konstruksi dan kesesuaian dengan IMB-R, serta pengawasan dan pengurusan 
perpanjangan terhadap berakhirnya masa berlaku IMB-R. Selanjutnya Dinas Pendapatan daerah melakukan pengawasan terhadap perpajakan bagi setiap penyelenggaraan reklame di Kota Denpasar.

Dinas Perhubungan melakukan pengawasan terhadap keselamatan dan keamanan berlalu lintas serta penyelenggaraan reklame yang memanfaatkan Jembatan Penyeberangan Orang dan halte dengan melihat kesesuaian penyelenggaraan reklame dengan aturan keselamatan dan keamanan berlalu lintas yang berlaku, serta kesesuaian dengan Rekomendasi teknis dari Dinas Perhubungan. Dinas kebersihan dan Pertamanan melakukan pengawasan terhadap pemanfaatan penempatan reklame di ruang terbuka hijau dan tiang penerangan jalan umum dari aspek estetika.

Berdasarkan uraian yang telah dijelaskan di atas, menurut Peraturan Walikota Denpasar Nomor 3 Tahun 2014 tentang Penyelenggaraan Reklame, mengenai kewenangan yang dimiliki oleh Pemerintah Kota Denpasar dalam penyelenggaraan reklame, dapat diketahui bahwa Pemerintah Kota Denpasar memiliki kewenangan untuk menerbitkan izin penyelenggaraan reklame serta melakukan pengawasan dan penertiban penyelenggaraan rekJame dengan menerapkan prinsip koordinasi, integrasi, dan sinkronisasi, guna menghindari penyalahgunaan kewenangan serta membagi tugas dan kewenangannya sesuai dengan fungsinya rnasing-masing. Koordinasi diperlukan agar setiap organisasi pemerintah daerah mengetahui pengawasan serta sistem kerja yang dilakukan oleh Tim Penyelenggaraan Reklame Kota Denpasar. Konsep pengawasan pemasangan papan reklame menentukan hasil pengawasan pemasangan, maka dalam hal ini penting untuk meningkatkan keoptimalan fungsi organisasi dalam pencapaian tujuan organisasi (Astika, 2018).

Berdasarkan hasil wawancara pada tanggal 1 Desember 2020 dengan Bapak Anak Agung Bagus Jimnantara Putra, SH selaku Kepala Seksi Penyelidikan, Penyidikan dan Penindakan Satuan Polisi Pamong Praja Kota Denpasar, upaya pemerintah kota Denpasar dalam mengatasi hambatan sarana pembongkaran reklame adalah dengan melakukan kerjasama kepada pihak lain yang dalam hal ini pekerja konstruksi reklame unruk melakukan pembongkaran terhadap reklame billboard dan LED. Jika ditemukan pelanggaran reklame pada ruas jalan maka Satuan Polisi Pamong Praja akan berkoordinasi bersama Dinas Perhubungan dan Dinas Kebersihan dan Pertamanan Kota Denpasar untuk melakukan upaya represif penegakan penyelenggaraan reklame. Pemerintah Kota Denpasar melalui Satuan Polisi Pamong Praja telah memberikan sanksi dan upaya represif, guna melakukan penertiban terhadap penyelenggaraan reklame demi tercapainya tata ruang kota yang indah dan keserasian penampilan Kota Denpasar.

Berdasarkan uraian yang telah dijelaskan di atas dapat diketahui bahwa Pemerintah Kota Denpasar telah melakukan upaya dalam menangani penyelenggaraan penertiban reklame di wilayah Kota Denpasar dengan melakukan upaya represif seperti membongkar reklame tidak berizin oleh Satuan Palisi Pamong Praja dengan bantuan beberapa anggota dari Tim Penyelenggaraan Reklame Kota Denpasar. Upaya preventif juga dilakukan dengan melakukan sosialisasi pengurusan izin reklame serta melakukan check and balance terhadap setiap pengurusan izin reklame. Upaya-upaya tersebut dilakukan guna meningkatkan pengawasan serta penegakan Peraturan Walikota Denpasar Nomor 3 Tahun 2014 tentang Penyelenggaraan Reklame, sehingga tercapai efektivitas hukum dari suatu peraturan yang telah diberlakukan.

\section{SIMPULAN DAN SARAN}

\section{Simpulan}

Dalam setiap penyelenggaraan reklarne terkait pemasangannya haruslah mengikuti prosedur dan tata cara yang diatur dalam aturan hukum terkait seperti yang diatur dalam Peraturan Walikota Denpasar Nomor 3 Tahun 2014, yang mana mengatur bahwa setiap pemasangan reklame haruslah disertai izin yang telah diperoleh dari PTSP dan Dinas Penanaman modal seperti izin IMB-R dan SIPR. lzin ini dapat bersifat permanen, insidentil hingga terbatas adanya sesuai lokasi dari perusahaan iklan tersebut. Dengan adanya izin ini, setidaknya, pemasangan reklame dapat terkontrol dan tetap memperhatikan aspek estetika atau keindahannya hingga keamanannya, selain itu aspek lain seperti isinya juga harus sesuai dengan norma kesusilaan serta kesopanan di masyarakat, tidak mengandung unsur sara. lni semua terkandung dalam Perwali Denpasar tentang penyelenggaraan reklame No.3 tahun 2014. Kewenangan dalam memberikan pengawasan serta penertiban penyelenggaraan reklame hingga penertiban izin menjadi wewenang Pemerintah Kora Denpasar, adapun prinsip yang harus dipegang yaitu tetap terintegrasi, berkoordinasi serta sinkron antara saru dengan lainnya, unruk 
menghindari penyimpangan dalam menyelenggarakan fungsi reklame ini. Dalam upaya penertiban, pemerincah Kota Denpasar secara preventif dan represif bertanggung jawab, seperti melakukan penyuluhan terkait tata cara penerbitan izin dan pegurusannya, hingga pengenaan sanksi administratif hingga pidana bagi pemasangan reklame tak memenuhi prosedur atau syarat atau tanpa izin dari pemerintah.

\section{Saran}

a. Dengan adanya Peraturan Walikota Denpasar dan ketetapan-ketetapan lainnya yang mengatur mengenai penyelenggaraan reklame di Kora Denpasar, maka hendaknya penyelenggara betul-betul taat terhadap aruran tersebut, dan pemerintah lebih memperketat peraturan terhadap permintaan penyelenggaraan reklame. Tentunya demi ketertiban dan keteraturan, khususnya demi terjaganya unsur estetika Kota Denpasar.

b. Hendaknya penertiban dan penindakan penyelenggaraan reklame yang tidak sesuai aturan I izin betul-betul dilakukan dengan jujur tanpa pandang bulu. Selain itu, dibarengi dengan penindakan atau penertiban, pemerintah hendaknya melakukan sosialisasi terkait Perwali Denpasar yang mengatur penyelenggaraan reklame di Kota Denpasar, sehingga penyelenggara reklarne juga mengetahui dan memahami peraturan - peraturan yang berlaku.

\section{DAFTAR PUSTAKA}

Astika, N. (2018). Pengawasan Pemasangan Papan Reklame di Kecamatan Tampan Kota Pekanbaru. Jurnal Online Mahasiswa Fakultas Ilmu Sosial Dan Ilmu Politik, 5(1), 1-12.

Boediningsih, W., \& Wijaya, M. (2015). Penegakan Hukum Terhadap Penyelenggaraan Izin Reklame di Kota Surabaya. Jurnal Sapientia et Virtus, 2(2), 141-156.

Nurcholis, Hanif. 2007. Teori dan Praktik Pemerintahan dan Otonomi Daerah. Grasindo. Jakarta.

Nurkukuh, D. K. (2019). Kajian Penataan Reklame di Koridor Jalan Affandi Yogyakarta. Prosiding Nasional Rekayasa Teknologi Industri Dan Informasi XIV, 1-6.

Ridwan HR. 2011. Hukum Administrasi Negara. PT. Raja Grafindo Persada. Jakarta.

Siregar, W., \& Suri, D. M. (2018). Analisis Pelaksanaan Kebijakan Penataan Pemasangan Reklame Luar Ruangan di Kota Pekanbaru. PUBLIKA : Jurnal Ilmu Administrasi Publik, 4(1), 176-190.

Sutedi, Andrian. 2010. Hukum Perizinan Dalam Sektor Pelayanan Publik. Sinar Grafika. Jakarta Sugeng, A. H. N., \& Sekarsari, R. W. (2019). Evaluasi Kebijakan Pemasangan Banner dan Papan Reklame Ilegal yang Mempengaruhi Keindahan Kota Malang. Jurnal Inovasi Ilmu Sosial Dan Politik, 1(1), 12-25.

Sunarno, Siswanto. 2012. Hukum Pemerintahan Daerah di Indonesia, Sinar Grafika. Jakarta.

Wirianto, Lukman. 2010. Peran Reklame lklan Dalam Mempromosikan Produk dan Jasa. Graha llmu, Jakarta. 